\title{
Using the Capability Approach to Conceptualise Inequality in Archaeology: the Case of the Late Neolithic Bosnian Site Okolište c. 5200-4600 BCE
}

\author{
V. P. J. Arponen ${ }^{1}$ • Johannes Müller ${ }^{2}$. \\ Robert Hofmann ${ }^{2}$ - Martin Furholt ${ }^{2}$. \\ Artur Ribeiro ${ }^{2}$. Christian Horn ${ }^{2}$ - Martin Hinz ${ }^{2}$
}

Published online: 14 May 2015

(C) Springer Science+Business Media New York 2015

\begin{abstract}
The past few decades have witnessed a growing realisation that marketbased measures of human well-being - measures that centre on income and consumption distributions - miss some other perhaps even more essential elements of human well-being. This insight has found a prominent expression in the work of the Nobel Prize-winning economist Amartya Sen's so-called capability approach. At the same time, the market-based measure of inequality as a function of the distribution of material remains in graves and other locations remain dominant in archaeology. In this paper, we explore the significance of the capability approach, and the associated concept of human well-being based on the idea of capabilities, to the archaeology of social
\end{abstract}

V. P. J. Arponen

varponen@gshdl.uni-kiel.de

Johannes Müller

johannes.mueller@ufg.uni-kiel.de

Robert Hofmann

robert.hofmann@ufg.uni-kiel.de

Martin Furholt

martin.furholt@ufg.uni-kiel.de

Artur Ribeiro

aribeiro@gshdl-uni.kiel.de

Christian Horn

chorn@gshdl.uni-kiel.de

Martin Hinz

mhinz@gshdl.uni-kiel.de

1 Graduate School "Human Development in Landscapes", University of Kiel, Leibnizstrasse 3, 24118 Kiel, Germany

2 Institute for Pre- and Protohistoric Archaeology, University of Kiel, Johanna-Mestorf-Strasse 2-6, 24118 Kiel, Germany 
inequality and social malintegration. We discuss these notions using the case study of the Late Neolithic Bosnian tell site Okolište and argue that there, in c. 5200-4600 BCE, the monopolisation of certain critical goods led to a critical capability inequality, malintegration and to a prolonged period of social unrest and decline.

Keywords Capability approach $\cdot$ Social inequality $\cdot$ Neolithic $\cdot$ Central Bosnia $\cdot$ House burnings

\section{Introduction}

Good life, it is often said, is about more than just money, material possessions and consumption. Such market-based measures - measures that centre on income and consumption distributions - of good life, of human thriving and human well-being more generally, are increasingly seen to stand in need of supplementing by other measures that focus on other, less material, aspects of a good life. One important attempt to conceptualise good life, human well-being and conversely inequality and social malintegration, in other than market-based terms, can be found in the work of the Nobel Prize-winning economist Amartya Sen.

Developed since the 1980s in a wide range of publications, Sen's capability approach has gained wide recognition in the academic world and beyond. Subject to ongoing academic debates (see Robeyns 2005), Sen's approach has served as the groundwork of a number of human well-being indexes, such as the Human Development Index of the United Nations Development Programme.

Sen's key idea is rather simple: human well-being is about what one is able to do and be, rather than what one possesses. 'Most social scientists and economists would agree', wrote Sen and the moral philosopher Martha Nussbaum, 'that GNP per capita is a crude and incomplete measure of quality of life; and yet such measures continue to be widely used when public policy is made' (Nussbaum and Sen 1993, p. 2). We would add that market-based measures do not have prominent proponents in public policy only, but also, among others, in archaeology. As will be illustrated below, there is a common belief in archaeology that inequality can be defined and measured accurately by simply observing the distribution of material remains in graves or other locations. Arguably, this is analogous to the market-based conception of human well-being, inequality and related phenomena in that both focus on the distribution of goods as the marker of social inequality, and it can therefore be subjected to Sen's critique.

In this paper, we discuss the significance of the capability approach in archaeology by the example of the Late Neolithic Bosnian site Okolište in c. 5200-4600 BCE. The decline around 4600-4300 BCE of agglomerated settlement patterns, the so-called tell settlements, after a period of intense economic and cultural productivity in various regions of Southeast Europe (both in Chalcolithic and Late Neolithic context) has been debated for decades (Childe 1929; Tringham 1971; Chapman 1990; Banffy 1991; Gimbutas 1994; Parkinson 2002; Link 2006; Rosenstock 2009; Hansen 2010; Hansen and Müller 2011; Hofmann et al. 2012). While archaeologists have formulated quite a number of different scenarios - from a violent destruction of agrarian societies by steppe intruders to a reduction of carrying capacities due to a changing climate - it was only in recent years that internal social questions have been included within the scope 
of research (e.g. Windler et al. 2013; Porčić 2012). Furthermore, newly emerging archaeological data indicate that we are not dealing with a short-term wave of invasion and change all over the Balkans, but that similar changes happened in different regions after similar structural developments at different points in time. Thus, the changes, which originally had been linked to one short phase of history, actually seem to have occurred over a span of perhaps c. 400 years (Link 2006). In this paper, we illustrate the value of adopting a capability approach to these developments as exemplified by the case study of Okolište.

Our paper is intended to make two different kinds of contribution to archaeology. On the one hand, it is a report of findings from Okolište attempting to explain the changes observed by archaeologists with respect to the excavated features, the material culture and the palaeo-ecological and economic data. Thereby, we hope to contribute to our understanding of the prehistory of that area. On the other hand, our paper is a contribution towards developing the capability approach as an original but overlooked theoretical resource in archaeology of social inequality.

\section{The Capability Approach}

The starting point of Sen's capability approach is the idea of "human life as a set of 'doings and beings"'. Therefore, Sen continues, 'the evaluation of the quality of life' is closely related 'to the assessment of the capability to function' or to do and to be (Sen 1989, p. 43). ${ }^{1}$ As such, Sen's approach can be seen to contrast with a number of alternative views on the quality of human life with focuses on 'personal utility (focusing on pleasures, happiness, or desire fulfilment)' or 'assessments of negative freedoms (focusing on procedural fulfilment of libertarian rights and rules of noninterference)' and many others (Nussbaum and Sen 1993, p. 30). In measuring human welfare, authors from the classic utilitarians to John Rawls had been interested in that actual something that a person with welfare gets (that her desires are fulfilled or that she has access to certain kind of goods), but with Sen's focus on capabilities, or functionings as he sometimes calls them, a new categorically different focus on doings and beings (rather than havings) was introduced (see Cohen in Nussbaum and Sen 1993).

The significance of Sen's starting point can perhaps be seen more clearly when contrasted with how human well-being - and relatedly, social (in)equality - is often thought in market-based terms of 'economic prosperity'; in particular, in terms of access to goods or commodities and income. In Sen's conception, the focus on economic prosperity affords only a limited view in that income and the possession of various types of goods are better conceived as mere means to quite other ends than mere possession. Sen conceptualises these ends as critical capabilities to do and to be. Therefore, Sen says, our analysis of human well-being should focus on the ends because the capability to seek to realise them, or the lack thereof, constitutes a more fundamental aspect of human well-being than market-based measures can capture.

\footnotetext{
${ }^{1}$ In the theoretical roots of his approach, Sen traces to figures like Aristotle (the concept of Eudaimonia or human flourishing) and classical political economists such as Adam Smith and Karl Marx (Sen 1989, p. 43). Sen's emphasis on doings can also be seen to chime well with the more contemporary philosophies of pragmatism and practice theory with the roots in the works of Ludwig Wittgenstein and Martin Heidegger (see e.g. Preucel and Mrozowski 2010; Schatzki et al. 2001; Dobres and Robb 2000).
} 
Sen's approach thus involves prioritising capabilities over other, not irrelevant but secondary, metrics such as lowness of income.

Illustrating well where the priority lies in Sen's position, he argues that 'poverty must be seen as the deprivation of basic capabilities rather than merely as lowness of income' where the deprivation to realise basic capabilities is the end of which the poor person is not capable with lowness of income at most bringing about this incapacity. Sen stresses that this view 'does not involve any denial ... that low income is clearly one of the major causes of poverty ... income can be a principal reason for a person's capability deprivation'. Sen's reasons for nonetheless prioritising capabilities include the aforementioned view that capabilities are 'intrinsically important' (ends) where income is only 'instrumentally significant' (means). In plainer words, Sen argues that differences in people's incomes and access to goods do not in and of themselves indicate inequality. Inequality comes in at the stage where low income and access to goods begin to limit a person's or group's critical capabilities to do and to be. That is, as long the person with low income is able to continue to exercise critical or other capabilities deemed desirable (say, to afford food and shelter or to participate in the activities of a social circle), income inequality does not constitute an impediment to leading a good life. Sen also points out that 'income is not the only instrument in generating capabilities', for 'the impact of income on capabilities', and therefore on human well-being, 'is contingent and conditional' on the person's and groups' wider social circumstances as well as their own characteristics (Sen 1999, p. 87). Sen's key tenet, then, concerns the need to study human well-being beyond the traditional economist focus on income and wealth distribution.

Obviously, the central terms of Sen's approach are those of critical capabilities and critical goods. In this paper, we follow Sen and leave the precise characterisation of critical capabilities and critical goods as open as possible, for on the one hand, Sen's own characterisation is like that, and on the other, this flexibility will be welcome when applying the capability approach in archaeology. ${ }^{2}$ Sen does mention basic needs such as adequate food, clothing and shelter as well as the importance of self-respect, social respect and social participation as essentially enabling a good human life. It is the first set of ideas having to do with basic needs upon which we draw in our case study, Okolište, below. We shall return to these issues in the closing section of the paper. Ultimately, we follow Sen in that 'doings and beings can be seen from different perspectives, with varying emphases' and that '[ $t$ ] he task of [further] specification [of the capabilities to do and to be] must relate to the underlying motivation of the exercise' that the researchers have undertaken (Sen 1989, pp. 45-46). This is welcome as it allows us to shape our understanding of the capabilities to do and to be to suit our archaeological purposes. Thus, for example, conceivably the capabilities relevant to a prehistoric person or a group, as well as the institutions in and through which these were or were not realised, were potentially of a very different kind than those pertaining to a modern person: while a modern person might long for occupational or educational opportunities as afforded or not to them by a political body of some kind, a prehistoric person might perhaps have operated within a network of kinship relations in a subsistence economy. The capability approach is flexible enough to allow us to apply

\footnotetext{
$\overline{2}$ Sen's collaborator, the philosopher Martha Nussbaum has developed a comprehensive account of capabilities in Nussbaum (2000).
} 
it in both kinds of worlds. For similar reasons, an archaeologist might fear that too strong an emphasis on freedom, in particular individual freedom, might be a point of view best applicable in discussions of modern, individualistic, societies that is not without further ado applicable to various ancient societies (cf. Geertz 1974 on the Western conception of the person).

To explicitly shift the focus away from the freedoms and capabilities of individuals, we want to mention here the work on social (mal)integration by the American philosopher Elizabeth Anderson (2010). ${ }^{3}$ She puts forward what she calls a 'relational view of group inequality'. 'Group inequalities', Anderson writes,

arise when a group has acquired a dominant position with respect to a critical good such as land or education and practices social closure to prevent other groups from getting access to these goods, except on subordinating terms. (Anderson 2010, p. 21)

This is a relational approach in that one group's access to critical goods is a matter of their relation to other groups who may be able to limit or otherwise set conditions to that access. The focus on groups, together with the idea of group inequality, is particularly welcome in the archaeological context in which social actors have been readily conceptualised as groups of some sort, family units for example, rather than as individuals. (For a good analytic elucidation of different aspects of individualism and the position of the capability approach to it, see Robeyns 2005, $107 \mathrm{ff}$.)

In this paper, our use of the terms 'critical capabilities' and 'critical goods' is informed by both Sen's and Anderson's ideas. By critical goods we mean various resources such as access to land or to education, as in Anderson, or respect and recognition, as in Sen, as well as certain critical or basic goods such as adequate food, clothing and shelter, as enabling the exercise of related core aspects of a good human life. The use of the term 'critical' is warranted by the idea that adequate food but also things like social respect make persons capable of activities (or doings and beings) that are critical to human well-being. These opportunities to realise immaterial and material capabilities and goods allow us to understand relationally as involving enabling or disabling relationships between social actors, groups or individuals. Although we do leave a closer characterisation of a critical good or capability quite open, we believe that in the sense of both Anderson and Sen, a critical good or a capability is essentially just that something critical, fundamental or foundational to human life and well-being. In this paper, we therefore speak of critical capabilities and critical goods with an emphasis on the word critical and deem it important that in further developments and applications of these ideas, this sense is adhered to.

\section{Social Inequality and Malintegration in Archaeology}

Archaeology - a science primarily focused on studying the material remains of a group of some kind - is perhaps naturally predisposed to study inequality in terms of the

\footnotetext{
${ }^{3}$ In the book, Anderson makes only an implicit reference to Sen's work acknowledging and appreciating its revisionary thrust (see Anderson 2010, Chap. 1, footnote 18).
} 
distribution of material remains in burials, houses and other identifiable locations. In archaeology, the distribution of material remains has, in turn, often been related to ideas about hierarchical leadership or other social structures of the social unit in question that the distributions are taken to indicate (see, e.g. Kohring 2011). In this section, we will critically discuss some selected examples from archaeology of inequality and indicate how the capability approach gives rise to a different picture of inequality.

Hence, looking at recent work on inequality in archaeology (Flannery and Marcus 2012; Bowles et al. 2010; Price and Feinman 2010, Chap. 3; see also Hansen and Müller 2011; Kienlin and Zimmermann 2012), we find that the perspectives on inequality there are mainly focused on the analysis of inequality as differences in social ranking. For example, in the introductory chapter to their edited volume, Price and Feinman (2010, p. 2) define inequality as concerning 'hierarchical structure in human society ... manifested in unequal access to goods, information, decision making, and power' saying that 'status differentiation is the foundation of inequality'. Looked at in this manner, inequality appears as a matter of social complexity, hierarchy and stratification, and can be studied, for instance, by determining the investment of labour into burials and public works as well as the distribution of goods in burials and households. A similar assumption, that social inequality is essentially a phenomenon appearing with the emergence of more and more complex and ranked societies, appears to underlie Kent Flannery and Joyce Marcus's recent highly impressive and wide-ranging study of the creation of inequality (Flannery and Marcus 2012).

We believe the capability approach distinguishes itself here in some important respects. It is customary in archaeology to relate observed distributions of grave goods, and various other kinds of depositions or any other archaeological evidence we find in the archaeological record, to the social statuses, roles, leadership structures etc., which the former potentially imply (as in Price and Feinman above). However, having with Sen defined human well-being, including social (in)equality and (mal)integration, as most essentially involving human critical goods and capabilities, it is necessary to relate the remains, statuses, roles and structures further to some limitations to act out critical capabilities and limitations to access critical goods. Therefore, the first crucial difference from the above-mentioned approaches to inequality lies in the idea that only by taking this latter step can we reach the essence of what makes up human well-being, and conversely, what makes up social inequality and malintegration. ${ }^{4}$

We thus propose a two-step argumentative structure: we argue or infer from, firstly, the archaeological record to social roles, structures and the like to, secondly, capabilities and thereby to (in)equality and (mal)integration. This two-step argumentative structure points out a weakness in direct inferences from differences in social status or role to inequality. Such an inference is seemingly implied in the received idea of a nonegalitarian society as an unequal society. Sen argues, however, that differences in income and consumption levels do not map one to one with the quality of human life, and therefore with the degree of social inequality within a society. Similarly, we raise the possibility that differences in status, ranking and role do not necessarily mean that

\footnotetext{
${ }^{4}$ Another issue related to current interpretations of inequality is the status of commodities, since in general, we tend to take these to be a direct measure of inequality levels. While the analysis of commodities does indeed produce valuable insights into economic processes and scales of transaction (Kopytoff 1986), it still leaves open the weight each commodity type has within different societies.
} 
those in inferior positions were limited in their critical capabilities and access to critical goods. Therefore, ranked societies or groups are not to be automatically thought of as unequal (this is implied in the notion of heterarchy, more of which below). In other words, following Sen's emphasis on doing and being, we argue that for a society to be ranked in various conceivable ways does not in itself necessarily imply anything much about the critical capabilities and goods that the ranked individuals have or have not, and that, therefore, whether their society is unequal or not. Inequality comes in at the second step when, and if, the ranking begins to affect the individuals' and groups' critical capabilities and access to critical goods.

One of the key methodological questions arising here is how to infer the active capabilities to act from the static archaeological record. As stated above, the capability approach involves rejecting the idea that access to goods, income and consumption in themselves have an inherent value from which one can infer inequality. Rather, if we consider a person as capable of performing functions, the goods found (in the archaeological record, for instance) must be seen as facilitating the functioning and that it is in that facilitating role - and not as mere possessions - through which they enter into questions about good or flourishing human life as well as inequality. In this view, a critical good is something that allows or improves the capability of an individual to perform a critical function. If we take the view that goods are a direct measure of inequality, it would mean that rare metals and objects should have greater economic value than quern stones, but through the lens of the capability approach, having a limited access to quern stones, for example, would mean a lack of the capability to process cereals, a capability that is critical, and perhaps, in the end, more critical than access to rare objects and metals.

We come now to the second distinctive aspect of the present approach. While in archaeology inequality tends to be simply equated with differences in distribution and access to material goods (Price and Feinman 2010 was given above as a representative example), we have a distinct absence of a discussion of actual events that signal the existence of social ills as a result of the distributive differences. That is, where possible in terms of the archaeological record, we should not limit our interest to snapshot views of a given society's distribution of goods, system of social ranking, statuses, roles and hierarchies, but also to look for signs that these actually led to socially problematic events which give us the reason to suppose that social differences actually meant inequality and malintegration. We intentionally leave open the precise import of the word 'event' here in that it may be used to cover not only events proper (such as the burning of the 'alpha houses' and the following breakup of the settlement of Okolište as discussed in our case study below) but also other phenomena observable in the archaeological record (say, an observed settlement size decline). Our reasoning here is that as inequality in Sen's sense is defined by the incapability to exercise critical capabilities and to access critical goods, where such a critical form of inequality is present, we are highly likely to witness serious social ruptures. Whether these ruptures are observable in the archaeological record is, of course, another matter.

We recognise that archaeological approaches to inequality and related themes have been very varied. Thus, in no particular order, we want to mention some other approaches and relate them to the capability approach. We begin by noting that the notion of heterarchy, proposed by some archaeologists (see, e.g. Crumley 2005) as a contrastive, and sometimes an alternative dimension of social organisation to that of 
hierarchy, ${ }^{5}$ seems to us to affirm a key tenet of the capability approach. This is to say, as the heterarchical form of organisation is characterised by the vertical spreading of different types of activity and associated status in society, it may be seen to view society in terms of members' (differing) doings and beings and hence to encourage the archaeological analyst to think in terms of the capability perspective. While different strands in the vertical spreading of society can enjoy differing accesses to goods and consumption, the actors active in these different strands must not be viewed as unequal unless the actors in different strands suffer from incapability with respect to critical capabilities and goods relative to actors in other strands. This corresponds closely to the key idea behind the capability approach: one may play a satisfactory role in society (and hence have well-being and not suffer from inequality) even if in society hierarchical structures and status differentiation obtain in the form that persons in some role or position generally have a lesser access to income, various types of non-critical goods and capabilities relative to persons in other roles. By contrast, it seems to us, many in archaeology have tended to treat hierarchical structures and status differentiation as the essence or 'the foundation of inequality' (Price and Feinman 2010, 2).

In 2010, the journal Current Anthropology published a special issue on inequality in pre-modern societies (Bowles et al. 2010). To a significant extent, the approach to inequality in these papers is similar to that of Price and Feinman 2010 focusing explicitly on 'economic inequalities' and studying inequality as revealed in 'opulent burials of children and other mortuary practices ..., the nature and distribution of ceremonial goods ..., the size of dwellings and storage facilities ..., and measures of stature and health' (Bowles et al. 2010, p. 8). They write that '[e]conomic and social inequality is generally measured by the extent of enduring differences among people or families in access to valued goods, services, or status" (Bowles et al. 2010, p. 8). However, as we saw above, in the capability approach's perspective, this fails to get to the bottom of human well-being by failing to relate distributions of valued goods, services and status further to critical goods and capabilities. That said, Bowles et al. ask interesting questions relevant to studying inequality as critical goods and capability deprivation such as regarding the 'kinds of wealth that are central to the livelihoods of' prehistoric groups including 'little-studied aspects of wealth such as the skills involved in subsistence production, social connections such as exist in food sharing or coalition networks, as well as land, livestock, and material possessions and the more commonly studied aspects of somatic wealth (such as body weight)' (Bowles et al. 2010, p. 8). On the whole, as exhibited by selected examples above, we get the impression that the distinction made in the capability approach between goods, services and status, on the one hand, and the capabilities that these do or do not give rise to, on the other, is typically not registered in archaeological work on inequality and related themes.

We also want to relate the present approach to the work of Jeanne Arnold on marginalisation (see Price and Feinman 1995, Chap. 3). Marginalisation, wrote Arnold, 'is the process by which established or emerging elites create socioeconomic relations of superior versus subordinate/dependent through manipulations of labour and

\footnotetext{
${ }^{5}$ It has, however, also been argued that "heterarchy has always, it seems, been thought of in relation to its accompanying other, hierarchy. Analyses of heterarchies display a search for powerholders, even if temporary ones, and thus continue to be part of an academic fascination with the functioning of (semi-)institutionalized political power" (Bernbeck 2012, 157; see also DeMarrais 2013).
} 
distributions of social resources' (Arnold 1995, p. 88). Arnold is here expounding a relational view seemingly very similar to that of Anderson discussed above: marginalisation derives from a lack of capability of some individuals or groups arising from their relations of dependency or control to others. Potential tools of marginalisation are characterised by Arnold as control over human labour ('labour brokering'), information and transportation (Arnold 1995, p. 88).

Despite the relational thrust of her conception of marginalisation, Arnold does not appear to view marginalisation as a matter of limited critical capabilities and limited access to critical goods. Instead, Arnold's text emphasises active 'elite strategies' and elites as 'opportunists' (Arnold 1995, p. 89) bringing about marginalisation through an active devising of ways to subject others to their control, whether by making use of emerging 'windows of opportunity' or creating them themselves. Such elite strategies might well be a real phenomenon, historically and today, but in the present view, taking note of them does not get to the bottom about the phenomenon of inequality. This is because, in the present view, inequality is not simply about somebody having power over others, but about the others thereby being somehow limited in their critical capabilities and access to critical goods.

\section{The Site of Okolište: an Overview}

Let us now turn to our case study. Okolište was excavated recently by modern methods as documented in the final publication of the project and elsewhere (Hofmann et al. 2006; Müller 2013; Müller et al. 2013a, b; Hofmann 2013; Dreibrodt et al. 2013). ${ }^{6}$ This tell site is situated in Europe, in the modern-day Bosnia-Herzegovina, in the Visoko basin, a naturally demarcated area of about $30 \mathrm{~km}^{2}$, surrounded by over $900 \mathrm{~m}$ high mountains, ${ }^{7}$ but linked to the 'outer world' by the river Bosna (see Fig. 1). Already during Neolithic times, this stream constituted an important exchange route for items, animals and people mediating influences between two highly innovative prehistoric regions: the central Danubian and the Adriatic.

Okolište was founded around 5200 BCE with a size of 7.5 hs and belongs to the regional Late Neolithic Butmir group. Up to nine settlement phases can be distinguished in the development of the site until around 4600 BCE when the site was abandoned (see Fig. 2). In the beginning, Okolište was enclosed by several ditches and banks, in contrast to the other much smaller sites in the Visoko basin. Also a local network of different economic and social activities could be observed between the settlements (Müller et al. 2011). While in Okolište, located in one of the most fertile areas of the basin, an agglomerated population of around $3000 \pm 1000$ inhabitants $^{8}$ had a

\footnotetext{
${ }^{6}$ The excavation of Okolište 2002-2009 was a project of the University of Kiel, the German Archaeological Institute and the National Museum of Bosnia-Herzegovina. In addition to financial and logistic support from the aforementioned institutions, the project was generously funded by the German Research Foundation.

${ }^{7}$ The figure of $30 \mathrm{~km}^{2}$ is an estimation of the area of the valley floor (suitable as arable land), a figure that can be extended up to $130 \mathrm{~km}^{2}$ if the surrounding hills and mountains (suitable for cattle herding) are included.

${ }^{8}$ Ethnographic analogies were used as a proxy to estimate the population size of the individual houses and the whole settlement (cp. Müller 2007, see also Müller 2013). The contemporaneity of houses was established from stratigraphic and spatial information. Furthermore, dating information, installation and house size were used for the interpolation of the average number of inhabitants.
} 


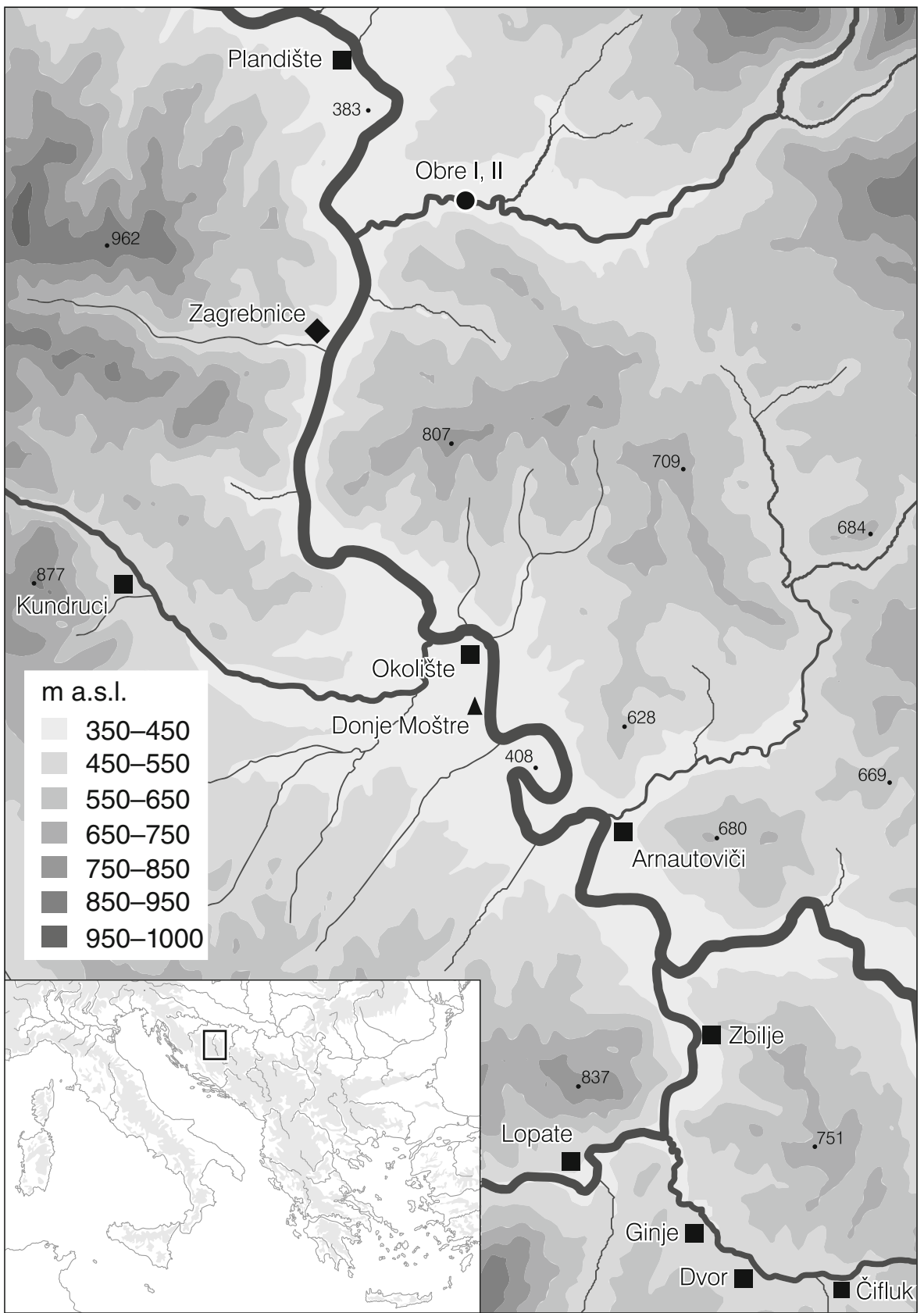

Fig. 1 The location of Okolište and neighbouring settlements in the Visoko Basin and Southeast Europe

high agrarian productivity, other sites such as Kundruci were much smaller $(0, .5 \mathrm{ha}$, $<100$ inhabitants) and specialised, in this case, in the production of Rock Crystal artefacts (Furholt 2012). Barter with cereals presumably took place. Other small sites existed that were 'poorly' agrarian (e.g. Zagrebnice) and probably in one way or 


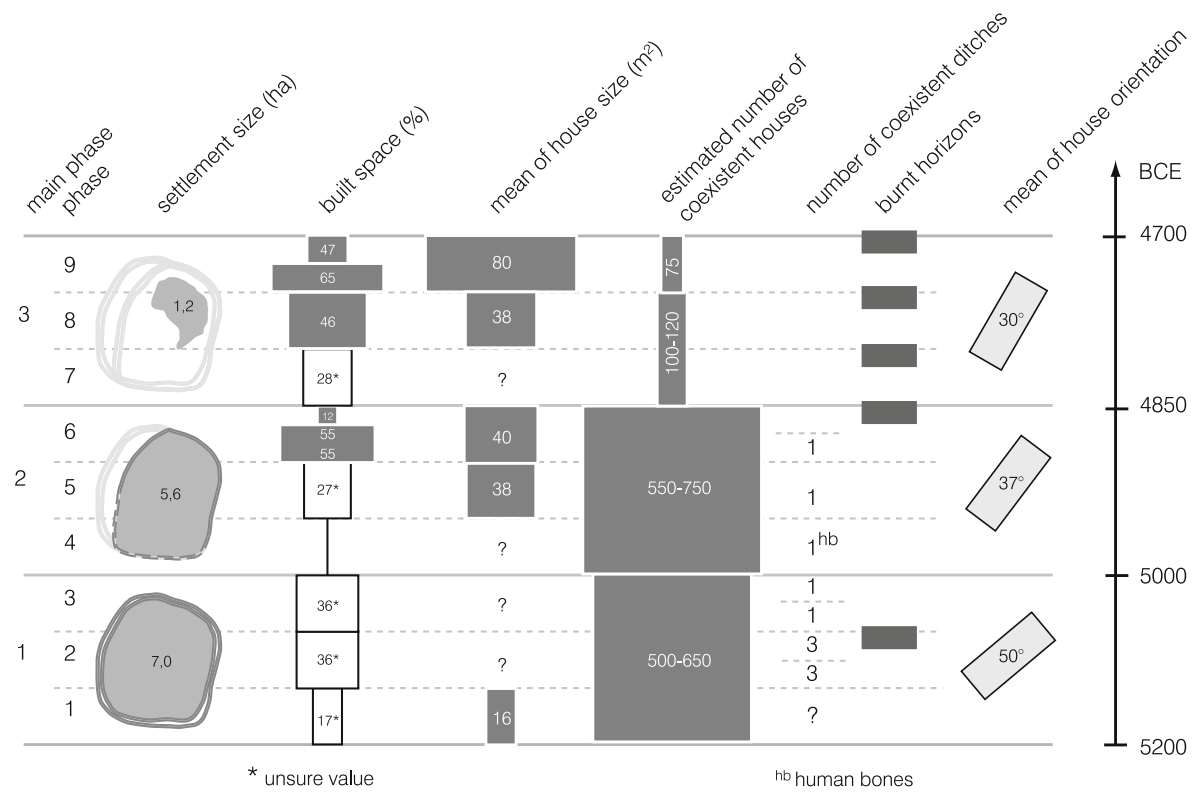

Fig. 2 An overview of some indicators of development and decline in Okolište from 5200 to 4700 BCE

another dependent on Okolište. Within the Visoko Basin, only at Okolište do we find certain exceptional items, such as small figurines, these being just one indicator of the exceptional status of this site (cf. Hofmann and Hofmann 2013).

Around $5000 \mathrm{BCE}$, within the Visoko Basin, different capabilities for social and economic activities appear to have been available to the inhabitants of the different settlements in the valley. In Kundruci and Zagrebnice, the inhabitants were active in mundane and specialised economic roles but had no monopoly on certain activities and items that were critical for the daily life of inhabitants in Okolište. Coming in very clear and lustrous but rather small bits of material, Rock Crystal was probably used for its aesthetic rather than utilitarian qualities, and was not as necessary a material as, for example, the dominant silex sourced some $110 \mathrm{~km}$ to the north at Trebačko Brdo (Hofmann et al. 2006, p. 128). Also, the missing enclosure in Zagrebnice and Kundruci may imply that such a piece of communal architecture (for defense) is only possible to be built for a certain sized population group and that in case of a threat, inhabitants of smaller villages might have retreated into the enclosed space of Okolište.

Okolište itself decreased in spatial size until c. 4850 BCE (see Fig. 2.), but at that point it was still one of the largest sites in the area, and still fortified. Around 4850 BCE, the destruction of the Okolište enclosure took place, accompanied by a sudden decrease in population size, resulting in a non-fortified village of 1.5 ha in size (200 \pm 100 inhabitants), that no longer differed from the other sites in the Visoko Basin (and also not from a typical Neolithic or Chalcolithic Balkan settlement). Next, we will show how examining the relational capability inequalities in the Visoko Basin, in particular within Okolište itself, helps us to understand the decline of the site. 


\section{Capability Inequalities Within Okolište}

A critical examination of the archaeological features and the distribution of material culture within these features indicate potential social conflicts resulting from differences in the access to critical goods and therefore to inequality of critical capabilities between the house places at Okolište. In that regard, the excavation trench 3 is of special interest. There, an area of $400 \mathrm{~m}^{2}$ was excavated and the remains of 15 houses (belonging to seven house places) uncovered (see Fig. 3).

The results of the analyses of material culture finds and features uncovered in this area do not conform to the hypothesis that every household in a Neolithic site functions in a similar and independent economic and social manner ('the segmented society'). Rather, on the one hand, the houses were quite similar in size (c. $4.5 \mathrm{~m}$ broad, $9 \mathrm{~m}$ long and c. $40 \mathrm{~m}^{2}$ ), they were similarly built (post-buildings with wooden reinforcement and clay infill) and with similar interiors (one room and one fire place) but, on the other hand, the items found in, and in the direct surroundings, of each house displayed clear differences with respect to production, distribution and consumption (Müller 2010; Müller et al. 2013).

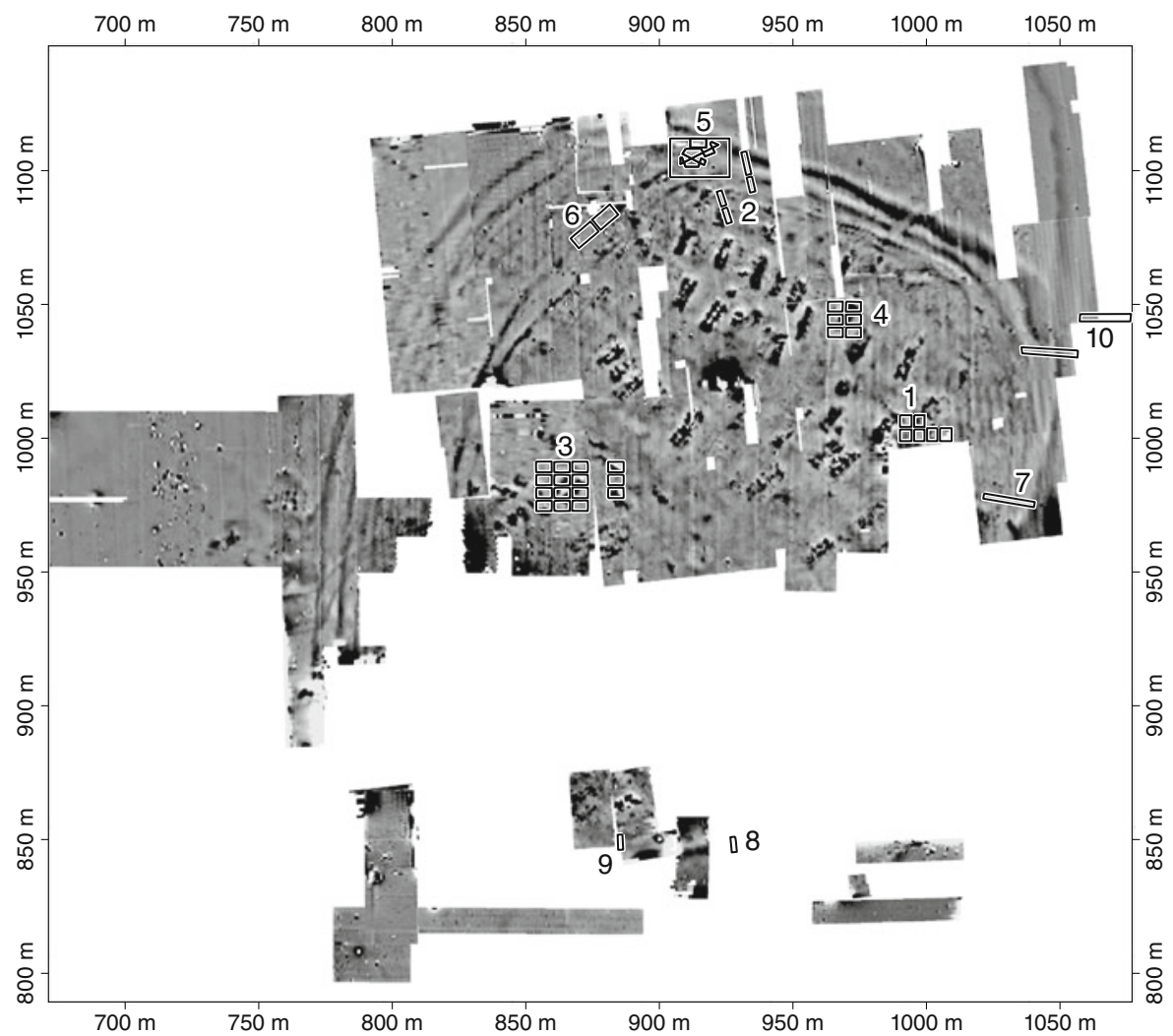

Fig. 3 Geomagnetic map of Okolište. Displayed are the numbered excavation trenches and geomagnetic features. Visible are burnt houses and different phases of the ditch/bank enclosure. Trench 3 is the area for which the detailed archaeological analyses of social relationships between households was conducted 
Thus, for example, cereal processing, necessary for the nutrition of all inhabitants, was concentrated in the house place $\mathrm{A}$ as evidenced in the highest number of grinding stones found there. Based on calculations from estimated inhabitant numbers per house and its size relative to the number of grinding stones found in that house, house A has about the fourfold capacity to surplus cereal processing compared with the other houses (see Fig. 14 in Müller et al. 2011), while at other house places cereal processing was practiced less (houses places B, E and F) or not at all (house place D) (see Fig. 4). The method of connecting material items with activities is explained in detail in Müller (2010) and Müller et al. (2013).

Another very important activity to provide for daily needs was 'weaving', and the archaeological evidence points to the monopolisation of 'weaving' in house places A and $\mathrm{C}$ as evidenced by high loom weight concentrations (see Fig. 17 in Müller et al. 2011). Furthermore, figurines that are generally seen as related to religious ritual communication were restricted to the same house places A and C. Based on these findings, we designate the houses $\mathrm{A}$ and $\mathrm{C}$ as 'alpha houses'. We also observed that the households with a surplus capacity in cereal processing (A) and cloth production (A and $\mathrm{C}$ ) are the households that exhibit a higher degree of different economic activities as well as demographic success (cp. Sahlins 1972). For these households, the spatial size of the house was larger (taken as a proxy of population size) and the variety of

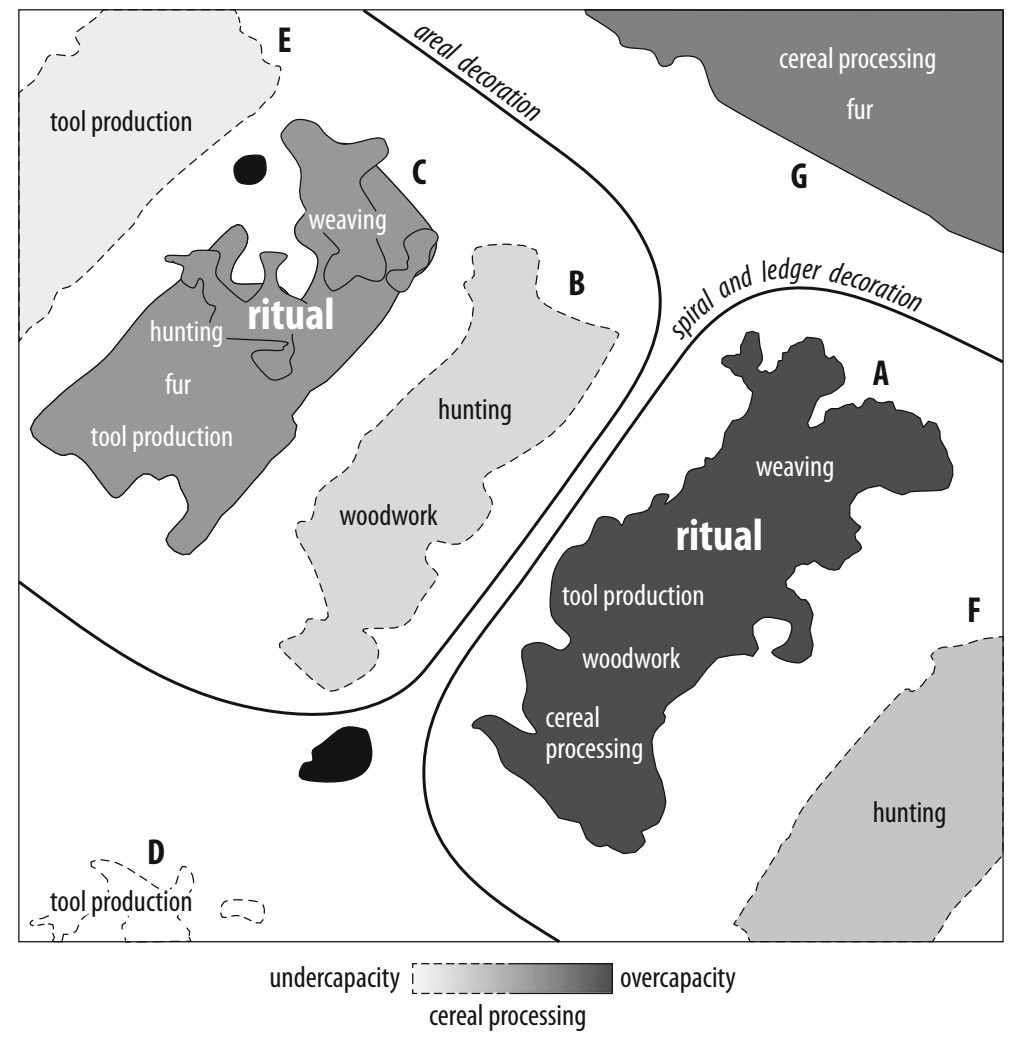

Fig. 4 A reconstruction of activities in households of trench 3. Over- and undercapacities to process cereals in the houses can be observed 
economic activities is very high in comparison with the other households. Also the difference in artefact quantities, especially the number of ceramic pots (as a measure for cooking, consumptive and storage activities) is much higher than in the other houses.

It is reasonable to believe that, given the location of the above-mentioned finds, we can establish a link between these finds and the activities associated with the settlement and these particular houses rather than explain these finds by reference to some a posteriori taphonomic processes. While there is evidence that some artefacts and sediments were displaced from some floor areas, they were deposited not too far from the houses, in the free spaces associated with the houses. Chronological analyses also confirm that the house places were occupied for four to six generations which adds up to 100-150 years of continual occupation (Müller et al. 2013; Hofmann 2013). Moreover, the possibility that the major differences found in the spatial distribution patterns of material culture were due to the burnt/unburnt structures or any other taphonomic processes has been ruled out by statistical testing. ${ }^{9}$ Even though the current paper focuses largely on material culture, the subsistence economy of the settlement is also supported by archaeobotanical and archaeozoological analysis (cp. Kroll 2013, in preparation; Benecke 2006; Hofmann et al. 2006). Thus, with this evidence it is possible to establish a solid link between the architectural features and the production and consumptions practices of Okolište.

Let us summarise the points made about capability inequalities in Okolište in the jargon of the capability approach. The monopolisation of cereal processing and cloth production by the alpha houses indicates that these houses had a monopoly on a range of associated critical goods, such as processed cereals, cloth and clothing. Further, these monopolies may imply the deprivation of other individuals, factions and families in this and other settlements of basic critical capabilities, such as access to cloth and the capability to adequately nourish oneself, which can result in further incapabilities of doing and being in life. The alpha houses appear to have been in effective control of these critical goods, and associated critical capabilities, allowing them to set the terms of access to these goods and control the capabilities of other individuals, factions and families. Also, in accordance with the two-step inferential process described above, we do not infer inequality from the mere differences in the distribution of material culture, but seek to further relate the differences to a lack of access to critical goods and, therefore, to lack of critical capabilities.

In contrast to these two alpha houses, the other five house places do not display monopolisation of critical goods and activities although we do find specialisation in hunting (in the house place F) and in tool production (house place $\mathrm{E}$ and at the space of house D after abandonment). Such specialisations imply certain internal dependencies between all households that also created the necessity of peaceful relationships between neighbours. However, such specialisation does not appear to have been enough to challenge the alpha houses as the dominant houses in Okolište. A general flourishing of the alpha houses, evident for instance in the above noted concentration of a range of

\footnotetext{
${ }^{9}$ Given that there was some displacement of sediment during the Neolithic in Okolište, the distribution of artefacts is quite fuzzy. However, the concentration of artefacts - such as the concentration of loom weights in clusters in the northeast corner of the houses - are in situ depositions. In contrast to the Vinca houses, the Butmir houses of Okolište and other sites have yet to reveal any deposition of items prior to the construction or after the burning of houses (cp. Chapman 1999; Verhoeven 2000; Twiss et al. 2008, p. 53 with Müller et al. 2013; Hofmann 2013).
} 
activities and demographic success, seems to indicate that somehow the alpha houses were able to turn their monopolies into dominance even when there was specialisation in some other houses. In the archaeological record, a clear correlation between the house size, the amount of cereal processing and weaving exists, while no other activity shows any overall correlation with house sizes or different activities. Consequently, the issues of access to cereal processing and weaving arguably constituted the most consequential aspects of the power relations between the households.

As we saw Anderson argue above, in the relational concept of inequality one group is able to limit and set the terms of another group's access. Arguably, in Okolište, we witness just such a situation in which, via the critical monopolies on cereal processing and cloth production, the alpha houses imposed limitations to the other groups and factions in Okolište, and the surrounding settlements, that apparently cancelled out whatever disadvantages the alpha houses may have had otherwise (such as that other houses may have specialised in hunting and tool production). While, on the one hand, as will be discussed in the next section, these contradictions within the system of dominance appear to have ultimately led to the system's destruction, on the other hand, specialisation also underlie the cooperative efforts that are necessary for each social order in the sense of Durkheim's division of labour in pre-modern societies (Durkheim and Luhmann 1999).

That the alpha houses were able to gain such a relationally dominant position seems to us to be supported also by the phenomenon of house burnings and the decline of Okolište discussed in the next section. As these abrupt changes around $4850 \mathrm{BCE}$ are linked to the establishment of new small settlements in the wider area (see Furholt 2012; Hofmann 2013; Müller et al. 2013b), the new dispersed settlement pattern might be the result of internal social 'stress' between households or other factions within the site of Okolište itself. This is even more probable as the original design of the spatial division within settlements (linear rows of houses) was practised throughout the entire development of c. 700 years without any significant change. The change of social roles between villages and inhabitants is quite clear, on a local level the dispersed settlement pattern reflects the equalising of access to critical goods and capabilities for the inhabitants in each of the settlements.

\section{Capability, Inequality and Decline}

In Late Neolithic and Chalcolithic tell sites burning of some of the houses has been observed (e.g. Chapman 1999; Link 2006) and we also observe such events in Okolište. A prominent interpretation, especially within post-processual, southeastern European and Near Eastern Archaeology, is to view such burnings as deliberate, ritual burnings connected to the idea of biographies of houses ending in their ritual destruction and 'burial' (e.g. Raczky 1983; Özdoğan and Özdoğan 1998; Chapman 1999; Verhoeven 2000, 2007). The idea of a ritual burning does not necessarily contradict our view. We believe that rituals are not detached from social power relations, but to the contrary, the exercise of rituals actually is an inherent constituent of such relations, especially in pre-modern societies (see Arponen and Ribeiro 2014). Therefore, in our view, a ritual burning could be seen as a culmination point of the critical inequalities discussed in this paper. 
Of considerable interest for the purposes of our study is the observation that it was the alpha houses that were burnt around 4850 BCE (see Fig. 2). For example, the alpha house A was destroyed in an apparently deliberate fire leading to the destruction of the position of the alpha houses within the settlement. For us it seems to be significant, that this destruction took place contemporary with the cessation of the use of the settlement's enclosure and the overall reduction of the settlement size.

Consequently, we identify the alpha house burnings as a culmination point of social ills providing us 'the event', or events, as discussed above, which show that the monopolisation of critical capabilities and access to critical goods was of the kind capable of arousing social tensions that subsequently lead to unrest. Social instability resulting from malintegration, even marginalisation of less capable groups and factions, was presumably the trigger of the events around 4850 BCE that changed the social structure of the settlement towards the kind of 'domestic mode of production' that Marshall Sahlins (1972) described as typical to Neolithic societies and that restricted the diversity of individuals and household towards the mould of a segmented society.

Interestingly, we also observe later burning events at Okolište (see Fig. 2) which could be interpreted as on-going struggles for dominance in a power vacuum created by the destruction of the alpha houses. As described elsewhere (e.g. Müller et al. 2011), the population size and the reconstruction of institutional life in Okolište, which integrated alpha households as the main players not only in some particular quarters, but also on the level of the village as a whole, was never reached again in the Visoko Basin. Thus, it appears that the reduction in settlement size was a further step to guarantee similar capabilities for at least a sufficiently large portion of members of the society. The case of Okolište describes a changing structure of the interrelations between households, groups and factions, perhaps down to individuals. The development of a new social formation of a stratified society (labelled by some as Tribal mode of production [Sahlins], by others as chiefdoms) is visible in the record, but the forces to counter such a development could be observed as well.

\section{In Closing}

The present authors differ on the question of whether limited access to ritual practices (implied in the distribution of figurines as noted above) can plausibly be conceptualised as limited access to a critical good and capabilities. Sen's formulation of the idea of critical goods and capabilities would seem to allow an affirmative as well as a negative answer. Sen counts the enjoyment of social participation as a critical capability, which means that depriving someone of social participation-participation in a ritual, for example - deprives them of a critical capability. Certainly, the availability of shared cultural capital, shared identity, symbols and representations has often been viewed as the foundation of human social existence and therefore also of human well-being (see Arponen and Ribeiro 2014).

On the other hand, access to food, clothing and shelter seem like critical goods of a wholly different category compared with access to ritual practices. For instance, depriving someone of access to ritual practices might lead the deprived to reject the ritual or to seek to replace these rituals by others. By contrast, depriving someone of food will lead to a different, more critical kind of deprivation with no fallback source 
of nutrition in the sense in which a ritual can in principle fall back upon some other ritual.

As an opinionated view of what 'really matters' for a good human life, namely the capabilities to do and to be (rather than, e.g. wealth and consumption), the capability approach raises deep questions about conceptualising social inequality and, by implication, social conflict, transformation and the foundations of human sociality. 'So far', Reinhard Bernbeck has argued, 'we have unproblematically mobilised the idea of collective identities, coherence and a desire of human beings to coalesce in groups, independently of space and time' (Bernbeck 2012, p. 157). Bernbeck can be read to echo here an essentially wider, interdisciplinary disquietude with the manner in which the emergence of social constructivism (in many ways a modern phenomenon, but with roots in 'counter-enlightenment', Berlin 1981) has served to intensify and normalise the focus in the human sciences upon notions such as identity, culture and ideology. These have often been understood as systems of shared cultural codes, of norms and values, and acquired by individuals in the process of enculturation that thereafter function 'as a kind of mental trace which disposes thought or action in a certain way' (Turner 1994, p. 43; see also Arponen 2013), a conception feeding on what has been called 'the myth of cultural integration' (Archer 1996). One important consequence of the constructivist focus on the mental drivers of human cultural action has been, as Bernbeck argued, that '[c]ultural anthropology, political science and sociology have become enamoured with the lifeworld of the powerful, their mentalities and practices,' which has 'dangerously shifted the balance in social and cultural fields of academic discourse away from a concern with those who are peripheralized, away from minorities, lower classes or the subaltern in general' (Bernbeck 2012, p. 147). Arguably, the archaeological record tends to be biased towards the visibility of those in power, but the capability approach is able to give a glimpse into the lives of the weakest, for they are the first in line to lose the only thing they can lose: their basic, critical capabilities. The capability approach powerfully suggests that ultimately at issue in social upheavals would not be issues of cultural codes, identity and the like, but something much more down to earth, basic and critical, namely, the access to critical goods and capabilities.

Closely related to the above, there is an on-going, decades long debate in political science about how to best theorise revolutions. Widely recognised as a modern classic contributor to the theory of revolution, Theda Skocpol argued that revolutions are temporally and spatially extended, ideologically complex phenomena in which "no single acting group, whether a class or an ideological vanguard, deliberately shapes', or rather is alone able to shape, 'the complex and multiply determined conflicts that bring about revolutionary crises and outcomes' (Skocpol 1985, pp. 86-87; see also Sewell 1985; Skocpol 1979). In a recent critical evaluation, John Foran (2005, p. 7) praised Skocpol, among others, for 'identifying the importance of large-scale participation' to revolutions and our understandings of them. The capability approach can be seen to present a certain back-to-basics perspective on revolutions: undoubtedly, complex political and symbolic processes go on in the case of revolutions as groups formulate, mobilise and agitate for their respective concerns. Arguably, however, a deep, popular uprising, with a large-scale, grass roots participation, can only take root, and the resulting revolution achieve a permanence, where matters of critical importance to good human life are involved and addressed, namely, the critical goods and capabilities to do and to be. 
Acknowledgments We would like to thank Lieske Voget-Kleschin for her comments to a draft of this paper. Naturally, the authors remain solely responsible for all views expressed in this paper.

Declaration of Conflicting Interests The authors declared no potential conflicts of interests with respect to the research, authorship, and/or the publication of this paper.

Funding The authors disclosed the following research financial support for the research, authorship, and/or publication of this paper: Robert Hoffman and Johannes Müller's research regarding Okolište was funded by the German Research foundation project Mu 1259/10-1-3 titled 'Die Rekonstruktion spätneolithischer Siedlungsprozesse in Zentralbosnien'. The remaining author's research was funded through the German Research Foundation's Graduate School Project (GSC 208) titled 'Human Development in Landscapes'.

\section{References}

Anderson, E. (2010). The imperative of integration. Princeton: Princeton University Press.

Archer, M. S. (1996). Culture and agency: the place of culture in social theory. Cambridge: Cambridge University Press.

Arnold, J. E. (1995). Social inequality, marginalization, and economic process. In T. Douglas Price \& G. M. Feinman (Eds.), Foundations of social inequality (pp. 87-103). New York: Plenum Press.

Arponen, V. P. J. (2013). The extent of cognitivism. History of the Human Sciences, 26(5), 3-21.

Arponen, V. P. J., \& Ribeiro, A. (2014). Understanding rituals: a critique of representationalism. Norwegian Archaeological Review. Forthcoming in 47(2).

Banffy, E. (1991). Continuity or discontinuity: some questions on the transition from the neolithic to the copper age in the Carpathian Basin. Antaeus, 19-20, 23-32.

Benecke, N. (2006). Archäozoologische Untersuchungen. Bericht der Römisch Germanischen Kommission, $87,159-161$.

Berlin, I. (1981). Against the current: essays in the history of ideas. Oxford: Oxford University Press.

Bernbeck, R. (2012). Multitudes before sovereignty: theoretical reflections and a late neolithic case. In T. L. Kienlin \& A. Zimmermann (Eds.), Beyond elites: alternatives to hierarchical systems in modelling social formations I (pp. 147-167). Bonn: Habelt.

Bowles, S., Smith, E. A., \& Borgerhoff Mulder, M. (2010). The emergence and persistence of inequality in premodern societies: introduction to the special section. Current Anthropology, 51(1), 7-17.

Chapman, J. (1990). Social inequality on Bulgarian Tells and the Varna Problem. In R. Samson (Ed.), Social archaeology of houses (pp. 49-98). Edinburgh: Edinburgh University Press.

Chapman, J. (1999). Deliberate house-burning in the prehistory of Central and Eastern Europe. In A. Gustafsson \& H. Karlsson (Eds.), Glyfer och arkeologiska rum-en vänbok till Jan Nordbladh (pp. 113-126). Göteborg: Göteborg Press.

Childe, V. G. (1929). The Danube in prehistory. Oxford: The Clarendon Press.

Crumley, C. L. (2005). Remember how to organize: heterarchy across disciplines. In S. Christopher \& W. W. Baden (Eds.), Nonlinear models for archaeology and anthropology: continuing the revolution (pp. 3550). Aldershot: Ashgate Publishing Limited.

DeMarrais, E. (2013). Understanding heterarchy: crafting and social projects in pre-hispanic Northwest Argentina. Cambridge Archaeological Journal, 23(3), 345-362.

Dobres, M. A., \& Robb, J. (Eds.). (2000). Agency in archaeology. London: Routledge.

Dreibrodt, S., Lubos, C., Hofmann, R., Müller-Scheeßel, N., Richling, I., Nelle, O., et al. (2013). Holocene river and slope activity in the Visoko Basin, Bosnia-Herzegovina - climate and land-use effects. Journal of Quaternary Science, 28(6), 559-570.

Durkheim, E., \& Luhmann, N. (1999). Über soziale Arbeitsteilung: Studie über die Organisation höherer Gesellschaften. Suhrkamp: Frankfurt am Main.

Flannery, K., \& Marcus, J. (2012). The creation of inequality: how our prehistoric ancestors set the stage for monarchy, slavery, and empire. London: Harvard University Press.

Foran, J. (2005). Taking power: on the origins of third world revolutions. Cambridge: Cambridge University Press.

Furholt, M. (2012). Kundruci: development of social space in a Late Neolithic Tell-Settlement in Central Bosnia. In R. Hofmann, K. Moetz, \& J. Müller (Eds.), Tells: social and environmental space (proceedings 
of the international workshop, socio-environmental dynamics over the last 12,000 years: The creation of landscapes II 14th-18th March 2011 in Kiel (pp. 203-219). Bonn: Habelt.

Geertz, C. (1974). From the native's point of view. On the nature of anthropological understanding. Bulletin of the American Academy of Arts and Sciences, 28(1), 26-45.

Gimbutas, M. (1994). Das Ende Alteuropas: Der Einfall von Steppennomaden aus Südrussland und die Indogermanisierung Mitteleuropas. Innsbruck: Inst. für Sprachwiss. der Univ.

Hansen, S. (2010). Leben auf dem Tell als soziale Praxis (Symposium Berlin 2007). Bonn: Habelt.

Hansen, S., \& Müller, J. (2011). Sozialarchäologische Perspektiven prähistorischer Gesellschaften: die Entstehung von sozialer Ungleichheit. Einführung in die Thematik der Tagung. In S. Hansen \& J. Müller (Eds.), Sozialarchäologische Perspektiven: Gesellschaftlicher Wandel 5000-1500 v. Chr. zwischen Atlantik und Kaukasus (Tagung Kiel 2007). Archäologie in Eurasien (pp. 3-12). von Zabern: Mainz.

Hofmann, R., Kujundžić-Vejzagić, Z., Müller, J., Müller-Scheeßel, N., \& Rassmann, K. (2006). Prospektionen und Ausgrabungen in Okolište (Bosnien-Herzegowina): Siedlungsarchäologische Studien zum zentralbosnischen Spätneolithikum (5300-4500 v. Chr.). Bericht der Römisch-Germanischen Kommission, 87, 1-140.

Hofmann, R. \& K. Moetz, et al. (2012). Tells: Social and Environmental Space (proceedings of the International Workshop Socio-Environmental dynamics over the last 12,000 Years: The Creation of Landscapes II 14th-18th March 2011 in Kiel) Universitätsforschungen zur prähistorischen Archäologie. Bonn: Habelt.

Hofmann, R. (2013). Okolište 2-Spätneolithische Keramik und Siedlungsentwicklung in Zentralbosnien., Neolithikum und Chalkolithikum in Zentralbosnien 2. Bonn: Habelt.

Hofmann, R., \& Hofmann, A. (2013). Anthropomorphe und zoomorphe Figurinen des Spätneolithikums aus Okolište und der Butmirgruppe in Zentralbosnien-Darstellungsmodi, Datierungen, Häufigkeiten, Herstellungstechniken und Fundkontexte. Offa, 69(70), 439-459.

Kienlin, T. L., \& Zimmermann, A. (Eds.). (2012). Beyond elites. Alternatives to hierarchical systems in modelling social formations. Universitätsforschungen zur prähistorischen Archäologie 215. Habelt: Bonn.

Kohring, S. (2011). Social Complexity as a Multi-Scalar Concept: Pottery Technologies, 'Communities of Practice' and the Bell Beaker Phenomenon. Norwegian Archaeological Review, 44(2), 145-163.

Kopytoff, I. (1986). The cultural biography of things. In A. Appadurai (Ed.), The social life of things: commodities in cultural perspective (pp. 64-91). New York: Cambridge University Press.

Kroll, H. (2013). Bericht über die Pflanzenfunde aus Okolište Haus 38. In: Müller, J., Rassmann, et al. (2013), pp 113-122.

Link, T. (2006). Das Ende der neolithischen Tellsiedlungen. Ein kulturgeschichtliches Phänomen des 5. Jahrtausends v. Chr. im Karpatenbecken. Universitätsforschungen zur Prähistorischen Archäologie 134. Bonn: Habelt.

Müller, J. (2007). Demographic variables and Neolithic ideology. In B. Spataro (Ed.), A Short Walk through the Balkans: the First Farmers of the Carpathian Basin and Adjacent Regions. Quaderno (12) (pp. 161170). Trieste: Trieste Società per la Preistoria e Protostoria della Regione Friuli-Venezia Giulia.

Müller, J. (2010). Zur Rekonstruktion des Mehrproduktes in neolithischen Haushalten. In I. Matuschik, C. Strahm, B. Eberschweiler, et al. (Eds.), Vernetzungen. Aspekte siedlungsarchäologischer Forschung. Festschrift für Helmut Schlichtherle zum 60. Geburtstag (pp. 51-62). Lavori Verlag: Freiburg.

Müller, J. (2013). Demographic traces of technological innovation, social change and mobility: from 1 to 8 million Europeans (6000-2000 BCE). In Kadrow \& Włodarczak (Eds.), Environment and subsistenceforty years after Janusz Kruk's “Settlement studies” (pp. 493-506). Rzeszów: Institute of Archaeology UR \& Verlag Dr. Rudolf Habelt GmbH.

Müller, J., Hofmann, R., et al. (2011). Zur sozialen Organisation einer spätneolithischen Gesellschaft in Südosteuropa (5200-4400 v.Chr.). In S. Hansen \& J. Müller (Eds.), Sozialarchäologische Perspektiven: Gesellschaftlicher Wandel 5000-1500 v. Chr. zwischen Atlantik und Kaukasus (Tagung Kiel 2007). Archäologie in Eurasien (pp. 81-106). von Zabern: Mainz.

Müller, J., Hofmann, R., et al. (2013a). Neolithische Arbeitsteilung: Spezialisierung in einem Tell um 4900 v. Chr. In A. Anders \& G. Kulcsár (Eds.), Moments in time. Papers Presented to Pál Raczky on His 60th Birthday (pp. 407-420). L'Harmattan: Budapest.

Müller, J., Rassmann, K., et al. (2013b). Okolište 1-Untersuchungen einer spätneolithischen Siedlungskammer in Zentralbosnien.. Universitätsforschungen zur prähistorischen Archäologie 228. Bonn: Habelt.

Nussbaum, M., \& Sen, A. (1993). The quality of life. London: Clarendon.

Nussbaum, M. (2000). Women and human development: the capabilities approach. Cambridge: Cambridge University Press. 
Özdoğan, M., \& Özdoğan, A. (1998). Buildings of cult and the cult of buildings. In G. Arsebük, M. J. Mellink, \& W. Schirmer (Eds.), Light on top of the Black Hill—studies presented to Halet Çambel (pp. 581-601). Istanbul: Ege Yayinlari.

Parkinson, W. A. (2002). Integration, interaction, and tribal 'cycling': the transition to the copper age on the great hungarian plain. In W. Parkinson (Ed.), The archaeology of tribal societies (pp. 391-438). Ann Arbor: International Monographs in Prehistory.

Porčić, M. (2012). Social complexity and inequality in the Late Neolithic of the Central Balkans: reviewing the evidence. Documenta Praehistorica, 39, 167-183.

Preucel, R. W., \& Mrozowski, S. A. (Eds.). (2010). Contemporary archaeology in theory: the new pragmatism (2nd ed.). London: Wiley.

Price, T. D., \& Feinman, G. M. (1995). Foundations of social inequality. New York: Plenum Press.

Price, T. D., \& Feinman, G. M. (2010). Pathways to power: new perspectives on the emergence of social inequality. New York: Springer.

Raczky, P. (1983). Origins of the custom of burying the dead inside houses in South-East Europe. Szolnok Megyei Muzeumi Evkonyv (1982-1983), 5-10.

Robeyns, I. (2005). The capability approach: a theoretical survey. Journal of Human Development, 6(1), 93114.

Rosenstock, E. (2009). Tells in Südwestasien und Südosteuropa. Remshalden: Greiner.

Sahlins, M. (1972). Stone age economics. New York: de Gruyter.

Schatzki, T. R., Knorr Cetina, K., \& von Savigny, E. (Eds.). (2001). The practice turn in contemporary theory. London: Routledge.

Sen, A. (1989). Development as capability expansion. Journal of Development Planning, 19(1), 41-58.

Sen, A. (1999). Development as freedom. Oxford: Oxford University Press.

Sewell, W. H. (1985). Ideologies and social revolutions: reflections on the French case. The Journal of Modern History, 57(1), 57-85.

Skocpol, T. (1979). States and social revolutions: a comparative analysis of France, Russia and China. New York: Cambridge University Press.

Skocpol, T. (1985). Cultural idioms and political ideologies in the revolutionary reconstruction of state power: a rejoinder to Sewell. The Journal of Modern History, 57(1), 86-96.

Tringham, R. (1971). Hunters, fishers and farmers of Eastern Europe: 6000-3000 B.C. London: Hutchinson University Library.

Turner, S. (1994). The social theory of practices: tradition, tacit knowledge and presuppositions. Cambridge: Polity Press.

Twiss, K. C., Bogaard, A., Bogdan, D., Carter, T., Charles, M. P., Farid, S., Russell, N., Stevanović, M., Nurcan Yalman, E., \& Yeomans, L. (2008). Arson or Accident? The Burning of a Neolithic House at Çatalhöyük, Turkey. Journal of Field Archaeology, 33(1), 41-57.

Verhoeven, M. (2000). Death, fire, and abandonment ritual practice at Late Neolithic Tell Sabi, Abyad, Syria. Archaeological Dialogues, 7, 46-83.

Verhoeven, M. (2007). Igniting transformations: on the social impact of fire, with special reference to the Neolithic of the Near East. In: S. Hansen (Ed.), Leben auf dem Tell als soziale Praxis. Beiträge des Internationalen Symposiums in Berlin vom 26.-27. Februar 2007 (pp. 25-43). Kolloquien zur Ur- und Frühgeschichte, 14. Bonn: Habelt.

Windler, A., Thiele, R., Müller, J., et al. (2013). Increasing inequality in Chalcolithic Southeast Europe: the case of Durankulak. Journal of Archaeological Science, 40, 204-210. 